\begin{tabular}{l|l|l|l}
$\begin{array}{c}\text { Case Reports in } \\
\text { Dematology }\end{array}$ & $\begin{array}{l}\text { Case Rep Dermatol 2011;3:64-67 } \\
\text { DOI: } 10.1159 / 000323182\end{array}$ & $\begin{array}{l}\text { Published online: } \\
\text { March 5, 2011 }\end{array}$ & $\begin{array}{l}\text { I 2011 S. Karger AG, Basel } \\
\text { ISSN 1662-6567 } \\
\text { www.karger.com/cde }\end{array}$ \\
\hline
\end{tabular}

\title{
A Long-Term Follow-Up of Angiolymphoid Hyperplasia with Eosinophilia Treated by Corticosteroids: When a Traditional Therapy is Still Up-to-Date
}

\author{
Serena Lembo Anna Balato Teresa Cirillo Nicola Balato \\ Department of Dermatology, University of Naples Federico II, Naples, Italy
}

\section{Key Words}

Angiolymphoid hyperplasia with eosinophilia - Epithelioid hemangioma · Follow-up ·

Kimura disease · Intralesional corticosteroids · Vascular disorder

\begin{abstract}
Angiolymphoid hyperplasia with eosinophilia (ALHE) is a rare and idiopathic vascular disorder. It is characterized by red to brown papules or nodules dislocated in the dermis or subcutaneous tissue. These lesions are typically localized on the head and neck, particularly around the ear as singular or multiple nodules. Although ALHE is a benign disease, lesions are often persistent and difficult to eradicate. ALHE can occur in all races, but it is reported more frequently in Asians. Young to middle-aged women are more commonly affected. The histological examination corresponds to a florid vascular proliferation with atypical endothelial cells surrounded by a lymphocytic and eosinophilic infiltrate. We describe the case of a 67-year-old Caucasian man with a nodular lesion in the right postauricular region for 3 years. The histological examination was consistent with ALHE. Monthly intralesional corticosteroid injections were performed for 6 months, and complete remission was achieved. After 10 years of followup, the patient is free of recurrence.
\end{abstract}

\section{Introduction}

Angiolymphoid hyperplasia with eosinophilia (ALHE) or epithelioid hemangioma is an uncommon vascular disorder. Inflammatory processes such as allergic reactions, traumas or autoimmune disorders are identified as possible causes. ALHE can occur in all races, but it is reported more frequently in Asians. Young to middle-aged women are 


\begin{tabular}{l|l|l|l}
$\begin{array}{c}\text { Case Reports in } \\
\text { Demmatoloyy }\end{array}$ & $\begin{array}{l}\text { Case Rep Dermatol 2011;3:64-67 } \\
\text { DOI: } 10.1159 / 000323182\end{array}$ & $\begin{array}{l}\text { Published online: } \\
\text { March 5, 2011 }\end{array}$ & $\begin{array}{l}\text { O 2011 S. Karger AG, Basel } \\
\text { ISSN 1662-6567 } \\
\text { www.karger.com/cde }\end{array}$ \\
\hline
\end{tabular}

more commonly affected. Typically, ALHE patients present with smooth-surface red to brown papules or nodules on the head and neck; most nodules are localized near the ear. Other less common sites include the trunk, extremities, genitalia, lips and oral mucosa; extracutaneous involvement is rare $[1,2]$.

The main differential diagnosis is Kimura disease [3], but other disorders such as facial granuloma, insect bite reaction, cutaneous lymphoma or sarcoidosis may imitate the clinical picture of ALHE [2].

\section{Case Report}

A 67-year-old Caucasian man was referred to our outpatient clinic with a 3-year history of an erythematous, elastic, hard nodular lesion in the right postauricular area (fig. 1). The lesion had gradually increased in size, measuring $3 \times 6 \mathrm{~cm}$ at our first observation; intense itch was reported. Topical corticosteroid treatment had not led to any improvement. Routine laboratory investigations were negative. A 4-mm punch biopsy was performed, and histologic analysis showed a florid vascular proliferation with atypical endothelial cells surrounded by lymphocytic and eosinophilic infiltrate (fig. $\underline{2} \mathrm{a}-\mathrm{d})$. Immunohistochemistry showed CD34-positive epithelioid cells (fig. 2c).

Based on these observations, a diagnosis of ALHE was made. Abdominal scan excluded any internal involvement. We decided to treat the patient with intralesional corticosteroid injections: $2 \mathrm{ml}$ of triamcinolone acetonide $(20 \mathrm{mg} / \mathrm{ml})$ once a month for 6 months. No additional topical treatment was given. The lesion gradually decreased and completely disappeared at the 7 th month. The patient attended our clinic for follow-up visits every second month for the first year after the remission, then every 6 months for 2 years. Since then, clinical evaluation has been performed every year. At 10 -year follow-up there was no evidence of recurrence.

\section{Discussion}

ALHE can have a spontaneous remission over the course of months or years, but symptomatic and disfiguring lesions may require treatment [4]. Multiple treatments have been proposed for disease management. Surgical excision is the treatment of choice, but as the lesions are often multilobulated and poorly delineated, local recurrences occur in 33-50\% after standard surgical excision. Mohs micrographic surgery with complete margin examination has been considered [5]. However, surgery can be disfiguring and difficult, especially in the case of periauricular lesions. Thus, other treatment options may be helpful; they include radiotherapy, curettage, shave excision with electrodessication, cryotherapy [6], corticosteroids (topical, systemic or intralesional preparation), and laser therapy. Continuous wave carbon dioxide and argon lasers have been successfully used, but there is a risk of scarring after treatment. Anecdotal reports have described other successful therapeutic options: intralesional interferon alpha-2a [7], indomethacin farnestil, pentoxifylline, chemotherapeutic agents such as vinblastine, mepolizumab (antiinterleukine-5) and imiquimod [8,9]. Furthermore, oral retinoids have been employed with different results [2].

Although all these innovative treatments have been reported for ALHE management, we would like to highlight this case because it could encourage the treatment with intralesional corticosteroids, which is a traditional therapeutic approach that still offers the advantage of being simple to perform and much less invasive than a surgical approach, while it achieves similar results in terms of recurrences and even better aesthetic outcomes. 


\begin{tabular}{l|l|l|l}
$\begin{array}{c}\text { Case Reports in } \\
\text { Dermatology }\end{array}$ & $\begin{array}{l}\text { Case Rep Dermatol 2011;3:64-67 } \\
\text { DOI: } 10.1159 / 000323182\end{array}$ & $\begin{array}{l}\text { Published online: } \\
\text { March 5, 2011 }\end{array}$ & $\begin{array}{l}\text { O 2011 S. Karger AG, Basel } \\
\text { ISSN 1662-6567 } \\
\text { www.karger.com/cde }\end{array}$ \\
\hline
\end{tabular}

\section{Disclosure Statement}

The authors have no conflicts of interest.

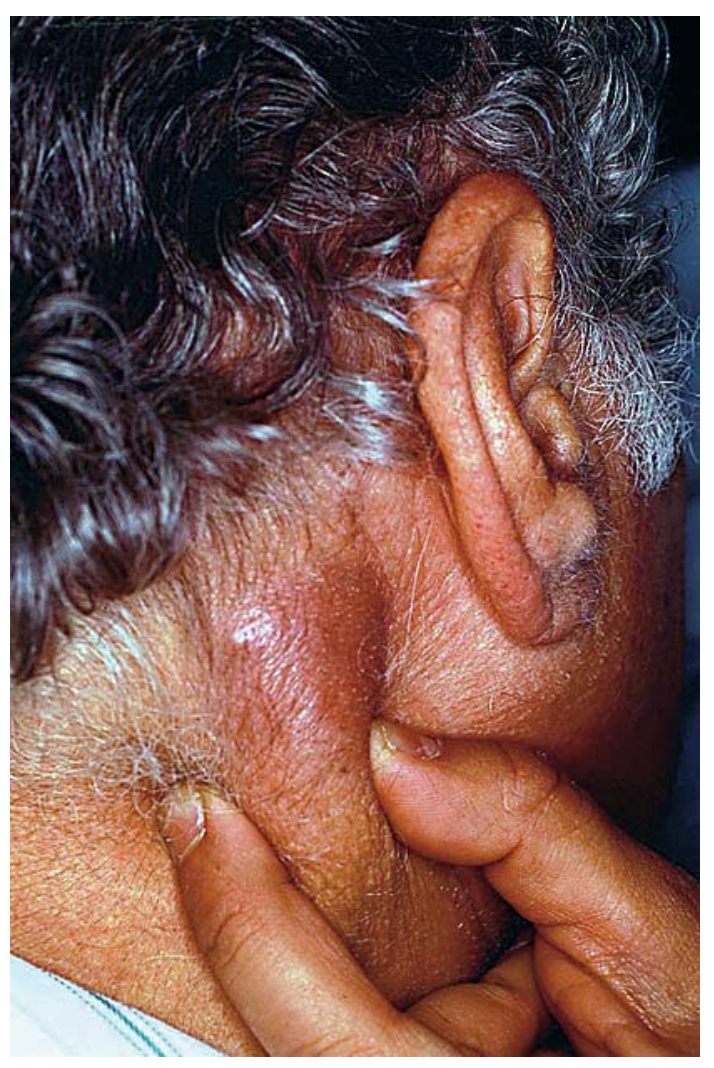

Fig. 1. Erythematous nodular lesion on the right subauricular area in a 67-year-old man. 


\begin{tabular}{l|l|l|l}
$\begin{array}{l}\text { Cosse Reports in } \\
\text { Dermatology }\end{array}$ & $\begin{array}{l}\text { Case Rep Dermatol 2011;3:64-67 } \\
\text { DOI: 10.1159/000323182 }\end{array}$ & $\begin{array}{l}\text { Published online: } \\
\text { March 5, 2011 }\end{array}$ & $\begin{array}{l}\text { O 2011 S. Karger AG, Basel } \\
\text { ISSN 1662-6567 } \\
\text { www.karger.com/cde }\end{array}$ \\
\hline
\end{tabular}

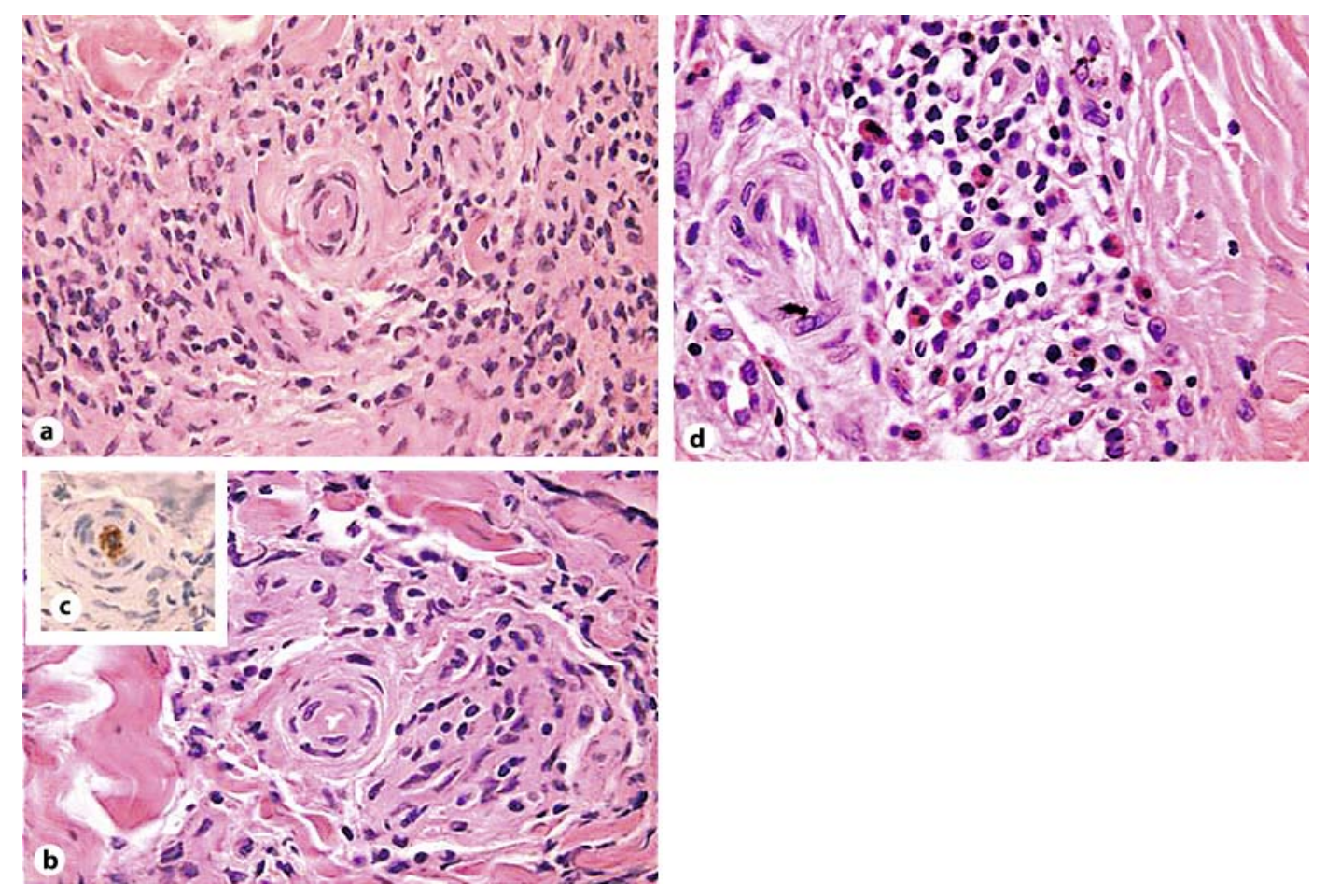

Fig. 2. Skin biopsy specimen from the lesion: hematoxylin-eosin stain, original magnification $\times 200$ (a, b), $\times 400$ (d), and CD34 immunohistochemical staining (c). a Immature vessels with single-layer endothelial cells surrounded by pericytes. b Enlarged endothelial cells with big ovoid nuclei and abundant eosinophilic cytoplasm protruding into the vascular lumen with a tendency to restrict or obstruct it. c CD34-positive epithelioid cells. d Mixed inflammatory infiltrate in the reticular dermis: lymphocytes, eosinophils and lymphoid aggregates with follicle formations.

\section{References}

1 Endo M, Shibata M, Iwamoto I, Suzuki H, Hayakawa M: Angiolymphoid hyperplasia with eosinophilia. Eur J Dermatol 1998;8:175-177.

2 El Sayed F, Dhaybi R, Ammoury A, Chababi M: Angiolymphoid hyperplasia with eosinophilia: efficacy of isotretinoin? Head Face Med 2006;2:32-36.

- Chun SI, Ji HG: Kimura's disease and angiolymphoid hyperplasia with eosinophilia: clinical and histopathologic difference. J Am Acad Dermatol 1992;27:954-958.

4 Kaur T, Sandhu K, Gupta S, Kanwar AJ, Kumar B: Treatment of angiolymphoid hyperplasia with eosinophilia with the carbon dioxide laser. J Dermatol Treat 2004;15:328-330.

-5 Miller CJ, Ioffreda MD, Ammirati CT: Mohs micrographic surgery for angiolymphoid hyperplasia with eosinophilia. Dermatol Surg 2004;30:1169-1173.

6 Wozniacka A, Omulecki A, Torzecka JD: Cryotherapy in the treatment of angiolymphoid hyperplasia with eosinophilia. Med Sci Monit 2003;9:CS1-CS4.

7 Shenefelt PD, Rinker M, Caradonna S: A case of angiolymphoid hyperplasia with eosinophilia treated with intralesional interferon alpha. Arch Dermatol 2000;136:837-839.

$\$ 8$ Braun-Falco M, Fischer S, Prötz SG, Ring J: Angiolymphoid hyperplasia with eosinophilia treated with antiinterleukin-5 antibody (mepolizumab). Br J Dermatol 2004;151:1103-1104.

-9 Redondo P, Del Olmo J, Idoate M: Angiolymphoid hyperplasia with eosinophilia successfully treated with imiquimod. Br J Dermatol 2004;151:1110-1111. 